\title{
Az irányítás mint az információs társadalom motorja
}

Beniger nagyszerű 1986-os, The Control Revolution című könyvének záró, s egyben összegző fejezete az információfeldolgozás, a kommunikáció és az irányítás központi jelentőségére irányítja rá a figyelmet. Úgy véli, hogy a társadalomtudósok az információval kapcsolatos alapvető fogalmak segítségével tisztázhatják a társadalom szerveződésével és a társadalmi folyamatokkal kapcsolatos, még mindig nagyrészt rendszerezetlen ismereteinket. Az információs társadalom kialakulását - a társadalmi viselkedés szinte valamennyi aspektusát tekintve - minden eddigi leírásnál ill. magyarázatnál jobban értelmezhetjük az irányítás rendszereiben végbemenő ciklikus változásokkal.

\section{Szerzői információ:}

James R. Beniger

A Dél-Kaliforniai Egyetemen, az Annenberg Kommunikációs Intézet Kommunikáció és Szociológia Tanszékének docense. A Harvard Egyetemen történelemből, a Kaliforniai Egyetemen pedig statisztikából szerzett diplomát, valamint ugyanitt szociológiából doktorált. Eddig megjelent könyvei: A vezérforradalom: az információs társadalom technológiai és gazdasági eredete (The Control Revolution: Technological and Economic Origins of the Information Society. Harvard University Press, 1986).

Így hivatkozzon erre a cikkre:

Beniger, James R. „Az irányítás mint az információs társadalom motorja”.

Információs Társadalom II, 2. szám (2002): 18-29.

https://dx.doi.org/10.22503/inftars.II.2002.2.2

A folyóiratban közölt müvek

a Creative Commons Nevezd meg! - Ne add el! - Így add tovább! 4.0

Nemzetközi Licenc feltételeinek megfelelöen használhatók. 
J a m e s R. B e n ige $r$

\title{
Az irányítás mint az információs társadalom motorja
}

\begin{abstract}
A nagy tudományos forradalom még várat magára. Akkor fog bekövetkezni, amikor az ember már képes lesz arra, hogy szisztematikusan alkalmazzon tudományos eljárásokat az emberi kapcsolatok és a rendelkezésére álló hatalmas technikai apparátus által a társadalomra gyakorolt hatások irányitására. A fizikai folyamatok szabályozásában elért tudományos eredmények története bizonyítja as irányitás lehetöségét a társadalmi jelenségek terén is.

John Dewey, Filozófia és Civilizáció (1931)
\end{abstract}

A második világháború után indult el az a folyamat, melynek során az Egyesült Államok, Kanada, Nyugat-Európa és Japán ipari gazdaságai az információs társadalom irányába mozdultak el. A munkaerő oroszlánrésze már információval összefüggố tevékenységekkel foglalkozik, és a jólét egyre inkább információs árukból és szolgáltatásokból származik. Noha minden eddigi emberi társadalom önfenntartása a vadászattól és gyüjtögetéstôl, a mezőgazdaságtól vagy az anyag és az energia feldolgozásától függött, az információfeldolgozással szemben az anyagfeldolgozás mára már elkezdett háttérbe szorulni.

Hogyan történhetett meg ez a váltás - és miért? Annak ellenére, hogy az információs társadalom eljövetelét számtalan múszaki szakkönyv és népszerû könyvek, illetve cikkek tömege hirdeti és dokumentálja, ezek közül egyetlenegy sem vetette fel - és még kevésbé válaszolta meg - ezt az alapvetô kérdést. Az emberek által értékesnek tartott dolgok között, hogyan kerülhetett domináns pozícióba - éppen a világ legnagyobb és legfejlettebb gazdaságaiban - az információ? Analógiaként: a tárgyi-anyagi kultúra szintén alapvetố jelentőségứ volt mindig is az emberi történelem folyamán, azonban a földet mint gazdasági bázist mégsem kezdte el felváltani a tôke - egészen az ipari forradalomig.

A válasz: az irányítás forradalma: azoknak a gyors változásoknak a komplex öszszessége, amelyek a műszaki és gazdasági életben az információ gyújtésével, raktározásával, feldolgozásával és közvetítésével foglalkozó szektorokban zajlanak le, amelyeken keresztül előírás-jellegú vagy programszerú döntések befolyásolhatják a társadalom irányítását. Az irányítás forradalma a XIX. század második felére tehető, kezdeteitôl fogva rendületlenül folytatódik mind a mai napig, és az utóbbi időben - a mikroprocesszoros technológia fejlődésével - ténylegesen fel is gyorsult. A XX. század történetében az irányítás forradalma - nagyságrendjét és a társadalomra gyakorolt hatásának mindent átható természetét tekintve, intellektuális és kulturális értelemben nem kevésbé, mint anyagi vonatkozásban - ugyanolyan fontosnak látszik, mint ami- 
lyen az ipari forradalom volt az elôző évszázadban. Éppúgy, mint ahogyan az ipari forradalom idején történelmi ugrást jelentett az „energia igába fogása”, az irányítás forradalma is hasonló drámai ugrást jelöl az információ hasznosítására irányuló képességeink fejlődésében.

Miért kezdődött az irányítás forradalma Amerikában a XIX. század közepén, szorosan követve az ipari forradalmat? Az időzítésre vonatkozó ilyen kérdések könynyebben megválaszolhatóvá válnak, ha tekintetbe vesszük, hogy a nemzetgazdaságok konkrét, nyílt feldolgozó rendszereket alkotnak, amelyek a környezetbôl származó input információk folyamatos kivonását, átszervezését és elosztását végzik a végsố fogyasztás céljából. A XIX. századig ezeket a funkciókat - a legnagyobb és legfejlettebb nemzetgazdaságokban is - még emberi léptékkel mérhetô sebességgel látták el, vagyis olyan feldolgozási sebesség mellett, amit csak kis mértékben fokozott az igavonó állatok, a szél- és vízi energia alkalmazása, és olyan rendszer-irányítás mellett, amit csupán szerény bürokratikus struktúrák nyújtottak. Mindaddig, amíg a rendszeren átbocsátott anyagok feldolgozására és mozgatására használt energia nem sokkal haladta meg az emberi munkával szolgáltatható energiát, egyéni dolgozók képesek voltak elvégezni azt az információfeldolgozást, amire szükség volt a rendszer irányításához.

Mihelyt azonbań az energiafogyasztás, a feldolgozás és a szállítás felgyorsul, és az irányításhoz szükséges információs követelmények szerepe láthatóvá válik, az ipari forradalom fogalma új értelmet kap. Ebből a szempontból nézve az ipari forradalomnak az volt messze a legnagyobb hatása, hogy felgyorsította a társadalom teljes anyagfeldolgozási rendszerét, ezáltal előidézve az irányítás válságát egy olyan idôszakban, amikor az információfeldolgozási és kommunikációs technika terén tett újítások elmaradtak az energia termelési, illetve szállítási célú felhasználásában bevezetett újításoktól.

\section{Válság és forradalom}

A 10.1. táblázat összefoglaló képet ad az irányítás válságáról, ami végigvonult a XIX. századi amerikai gazdaság valamennyi területén, a közlekedéstôl (vasutak) az elosztásig (bizományosi kereskedelem és nagykereskedelem), majd a termelésig (acélmúvek, más fémgyártási és fémfeldolgozó iparágak) és a marketingig (folyamatos üzemû iparágak). Az, ami az 1840-es évek elején a vasúti közlekedés és szállítás biztonságának válságaként kezdődött, az 1850-es években elérte az elosztást, majd az 1860 as évek második felében a termelést, s végül az 1880-as évek elején a marketinget és a fogyasztás irányítását is.

10.1 táblázat: Fontosabb válságok a szállítmányozás, a termelés, az elosztás és a fogyasztás irányításában, 1840-tôl 1889-ig

\begin{tabular}{l|l} 
Év & \multicolumn{1}{c}{ Válság } \\
\hline 1841 & $\begin{array}{l}\text { A Western Railroad vasúttársaságnál történt vonatszerencsétlenségben két } \\
\text { halott, tizenhét sebesült. Massachusetts állam törvényhozása vizsgálatot ren- } \\
\text { del el. }\end{array}$ \\
\hline 1849 & $\begin{array}{l}\text { Az áruszállítmányokat kilenc alkalommal kell átrakodni Philadelphia és } \\
\text { Chicago között, ami hátráltatja az elosztási hálózatok múködését. }\end{array}$
\end{tabular}


1851-54 | Az Erie Railroad vasúttársaság múködésében „súlyos zavarok” kezdôdnek a keleti és a nyugati partot összekötổ első fővonalon, hónapokon át tévesen irányítanak egyes vagonokat.

1850-es évek $\quad$ A gabonasilók és raktárak hálózatának bôvülése, valamint a tömeges áruszállítás és raktározás iránt megnyilvánuló növekvố igény mellett a teherszállítással foglalkozó vállalatok egyre nagyobb nehézségekkel tudják csak nyomon követni az egyes gabona- és gyapotszállítmányokat.

1850-es és 1860-as évek $\quad$ A kereskedelmi vállalatok egyre kevésbé képesek ellenőrzésük alatt tartani a búza-, kukorica- és gyapottermés növekvố kereskedelmi forgalmát. Az áruforgalmat jutalék fejében lebonyolító kereskedôk egyre kevésbé tudják kézben tartani a tömegtermeléssel előállított fogyasztási cikkek elosztását.

1860-as évek $\quad$ A gyors teherszállítmányokat és expresszvonatokat múködtetố vállalatok kialakulásának következtében a vasúttársaságok nehézségekkel küzdenek a vonalaikon futó „idegen” tehervagonok aktuális helyének és az azok által megtett utak hosszúságának nyilvántartásában.

A nagykereskedők - több száz gyártó és több ezer kiskereskedố között közvetítve - egymással versengenek az áru- és készpénzforgalom integrálásáért. A folyamatos üzemú technológiát alkalmazó olajtermelők, akik miközben az egységre számított költségeik felére csökkennek - háromszorosára-hatszorosára emelik termelésüket, rákényszerülnek, hogy ösztönözzék a fogyasztást, differenciálják termékeiket és kiépítsék a márkahúség intézményét.

1860-as évek vége $\quad$ A Bessemer eljárást alkalmazó acélmúvek küzdenek az acélgyártás megnövekedett sebességének kézbentartásáért. A nagykereskedôk és az olyan kiskereskedelmi egységek, mint például az áruházak, igen gyors raktárkészletforgási sebesség igényével néznek szembe.

\begin{tabular}{l|l}
\hline 1870 -es évek & A vasúttársaságok (a Pennsylvania kivételével) késlekednek a nagy rendszerek
\end{tabular} kiépítésével, mert hiányoznak az eszközeik azok irányítására.

Az alapvetố nyersanyagok - a vas, a réz, a cink és az üveg - termelôi saját üzemeiken belül küszködnek a gyors, versenyképes átbocsátás biztosításáért.

A nagy kereskedőházak, amelyek a XIX. század legdifferenciáltabb szervezeti struktúrái közé tartoznak, szükségesnek találják, hogy egyre több erốsen specializált szervezeti egységet integráljanak.

\begin{tabular}{l|l}
\hline 1882 & Henry Crowell, aki folyamatos üzemú technológiát alkalmaz a zabpehely elóál-
\end{tabular} lítására, az országos fogyasztási igény kétszeresét termeli és új piacok megteremtésére kényszerül.

1880-as évek A fémfeldolgozó iparágak - az öntöttvas- és csavargyáraktól a varrógép-, írógépés villanymotor-gyártó üzemekig - azért küzdenek, hogy a feldolgozásban a tömeg és a sebesség tekintetében egyaránt lépést tudjanak tartani a fémnyersanyag-gyártókkal.

A folyamatos üzemű technológiákat alkalmazó liszt-, szappan-, cigaretta-, gyufa-, konzerv-és filmgyártó vállalatok új piacok megteremtésének, valamint a fogyasztás ösztönzésének és irányításának a szükségletével néznek szembe. A nagyvállalatok múködtetéséhez szükséges információfeldolgozás - a leltározás, a számlázás és az eladási adatok elemzése - terén a komplexitás, a sebesség és a növekvő méretek kezdik szétfeszíteni a kézi feldolgozórendszerek kapacitását. 
Ahogy az irányítás válsága fokozatosan kiterjedt az egész gazdasági életre, az innováció fontos kérdéssé vált az irányítástechnikában. Azok az újítások, amelyek kihatottak a szállítmányozókra, a termelókre, az elosztásban és az értêkesítésben dolgozókra egyaránt, az 1880-as évekre már általánossá vált. A válságra újítások özönével és a bürokratikus irányítás gyors fejlődésével adott múszaki és gazdasági válasz - az irányítási forradalom -, amely a XX. század elejére szerte a világon már elkezdte átalakítani a társadalmat.

A 10.2. táblázat részleges összefoglalást ad azokról az információs technológia terén bevezetett fontosabb újításokról, amelyekból a XIX. századi irányítási forradalom összetevődik, legalábbis az Egyesült Államokban. Bemutatja ennek a forradalomnak az információs társadalom felé vezető úton végbement további kibontakozását az 1930-as évekig. Az újításoknak ez a listája feltárja a szervezési, információfeldolgozási és kommunikációs technikák szakadatlan fejlődését, legalábbis az 1850-es évektôl az 1880-as évekig tartó évtizedekben, egy olyan időszakban, amelyik talán tíz-húsz évvel is késleltette az iparosítást. Figyelemreméltó a lista éles periodicitása. A három fő gazdasági szektort tekintve az 1860-as évekig gyakorlatilag az összes fóbb irányítási újítás az elosztás terén található, míg az 1870-es években és azután az újítások súlypontja áttevődik a termelésre és a fogyasztásra. Az elosztás terén a fontosabb események többsége 1870 előttre tehetô, míg a termelésben és a fogyasztásban szinte valamennyi lényeges újítás ez után az idő́pont után következik be, az áltạlános értelemben vett irányítás fóbb újításai pedig sporadikusan jelennek meg az egész idôszak során).

10.2. táblázat: Válogatott újítások a termelés, az elosztás és a fogyasztás irányításában, valamint az általános érdekû́ irányítás terén, 1830-tól 1939-ig.

\begin{tabular}{|c|c|c|c|c|}
\hline$\underline{E_{V}}$ & Termelés & Elosztás & Fogyasztás & Általános \\
\hline 1830 & & $\begin{array}{l}\text { Menetrendszerú } \\
\text { teherszállítmányok }\end{array}$ & & \\
\hline \multicolumn{5}{|l|}{32} \\
\hline 34 & & & $\begin{array}{l}\text { Penny rendszerú } \\
\text { nyomda }\end{array}$ & \\
\hline \multicolumn{5}{|l|}{36} \\
\hline 38 & Szerszámgépgyártás & Telegráf & & \\
\hline 1840 & & \begin{tabular}{|l|} 
Gyorsáruszállítás, \\
közvetlen szállítmányok
\end{tabular} & Dagerrotípia & \\
\hline 42 & $\begin{array}{l}\text { Amerikai gyártási } \\
\text { rendszer }\end{array}$ & & Reklámügynök-ségek & $\begin{array}{l}\text { Nagy méretú } \\
\text { formális szervezetek }\end{array}$ \\
\hline \multicolumn{5}{|l|}{44} \\
\hline 46 & & Csomagolás & Hoe-féle nyomda & \\
\hline 48 & Szabványos huzalmérce & Árucsere & Újságíró-szervezetek & \\
\hline \multicolumn{5}{|l|}{1850} \\
\hline 52 & Megbízott ipari & Postabélyeg & Facelluloz, rongypapír & $\begin{array}{l}\text { Hierarchikus folya- } \\
\text { matirányítási rendszer }\end{array}$ \\
\hline 54 & & Közvetlen fuvarlevél & & \\
\hline 56 & & $\begin{array}{l}\text { Ajánlott postai } \\
\text { küldemények }\end{array}$ & $\begin{array}{l}\text { Iterációs eljárással } \\
\text { készült másolatok }\end{array}$ & \\
\hline
\end{tabular}




\begin{tabular}{|c|c|c|c|c|}
\hline 58 & $\begin{array}{l}\text { Nagyságrendekkel } \\
\text { bốvülő vasúthálózat }\end{array}$ & & Betûszedôgép & $\begin{array}{l}\text { „Line-and-staff” } \\
\text { irányítás }\end{array}$ \\
\hline 1860 & $\begin{array}{l}\text { Folyamatos üzemú } \\
\text { technologia }\end{array}$ & $\begin{array}{l}\text { Határidốs kereskedelmi } \\
\text { ügyletek, váltók }\end{array}$ & & $\begin{array}{l}\text { Változatos kiemelố } \\
\text { betútípusok }\end{array}$ \\
\hline 61 & & & $\begin{array}{l}\text { Karácsonyi vásár } \\
\text { reklámok }\end{array}$ & \\
\hline 62 & & Papírpénz & & \\
\hline 63 & & Rögzített árak & & \\
\hline 64 & & $\begin{array}{l}\text { Postai } \\
\text { pénzküldemények }\end{array}$ & & \\
\hline 65 & & & $\begin{array}{l}\text { Kedvezményes vásárlási } \\
\text { kuponok }\end{array}$ & \\
\hline 66 & & $\begin{array}{l}\text { Transz-atlanti kábeles } \\
\text { összeköttetés }\end{array}$ & & \begin{tabular}{|l|}
$\begin{array}{l}\text { Több osztályra tagolódó } \\
\text { modern hivatali } \\
\text { szervezet }\end{array}$ \\
\end{tabular} \\
\hline 67 & & & & \\
\hline 68 & Bessemer eljárás & $\begin{array}{l}\text { Utazó kereskedelmi } \\
\text { ügynökök }\end{array}$ & & $\begin{array}{l}\begin{array}{l}\text { Ujság-elófizetési rend- } \\
\text { szer }\end{array} \\
\end{array}$ \\
\hline 69 & & & & \\
\hline 1870 & \begin{tabular}{|l|} 
Nyersanyagok \\
folyamatos feldolgozása
\end{tabular} & & Védjegytörvény & \\
\hline 71 & & & $\begin{array}{l}\text { Emberközpontú } \\
\text { hirdetések }\end{array}$ & \\
\hline 72 & & Postai megrendelések & & \\
\hline 74 & "Shop-order" könyvvitel & Nagy üzletláncok & Illusztrált napilapok & $\begin{array}{l}\text { Írógép QERTY-billen- } \\
\text { tyưzettel }\end{array}$ \\
\hline 75 & $\begin{array}{l}\text { Gyorsított feldolgozást } \\
\text { célzó üzemtervezés }\end{array}$ & $\cdot$ & $\begin{array}{l}\text { Hetenként megjelenó } \\
\text { reklámújságok }\end{array}$ & \\
\hline 76 & & Telefon & & \\
\hline 77 & & & & \\
\hline 78 & & $\begin{array}{l}\text { Telefon kapcsolótáblák, } \\
\text { telefonközpontok }\end{array}$ & $\begin{array}{l}\text { Egész oldalas } \\
\text { hirdetések }\end{array}$ & \\
\hline 79 & & & & \\
\hline 1880 & & & & \\
\hline 81 & & & Új védjegytörvény & Közgazdasági képzés \\
\hline 82 & & & & Dow Jones index \\
\hline 83 & & Egységes zónaidốk & $\begin{array}{l}\text { Tömegesen terjesztett } \\
\text { napilapok }\end{array}$ & $\begin{array}{l}\text { Számviteli és könyvelési } \\
\text { szolgáltatást végző } \\
\text { vállalatok }\end{array}$ \\
\hline 84 & $\begin{array}{l}\text { Norma-megállapítási } \\
\text { osztályok, } \\
\text { költségellenőrzés }\end{array}$ & Expressz postaszolgálat & Újság szindikátusok & $\begin{array}{l}\text { Vámszabad raktározási } \\
\text { vállalatok }\end{array}$ \\
\hline 86 & & & Sorszedógép & Íróasztali telefon \\
\hline 87 & Blokkoló óra & & & \\
\hline 88 & & & Hirdetési folyóiratok & Lyukkártyás tabulátor \\
\hline 89 & & $\begin{array}{l}\text { Szállítmányokat } \\
\text { nyilvántartó irodák }\end{array}$ & \begin{tabular}{|l|} 
Szenzációk közlése \\
országos viszonylatban
\end{tabular} & \\
\hline
\end{tabular}




\begin{tabular}{|c|c|c|c|c|}
\hline 1890 & $\begin{array}{l}\text { Munkafelügyelet a } \\
\text { szállítás-irányítás } \\
\text { biztosítására }\end{array}$ & & & Stencil \\
\hline 91 & & $\begin{array}{l}\text { Nyilvános telefonfülkék, } \\
\text { utazási csekkek }\end{array}$ & $\begin{array}{l}\text { Szabványosított } \\
\text { hirdetôtáblák }\end{array}$ & Szorzógép \\
\hline \multicolumn{5}{|l|}{92} \\
\hline 93 & & & $\begin{array}{l}\text { Nyomdatechnikai } \\
\text { szabadalmak }\end{array}$ & Postai címezogép \\
\hline 94 & & & Hivatásos újságírók & $\begin{array}{l}\text { Négyfunkciós } \\
\text { számológép }\end{array}$ \\
\hline \multicolumn{5}{|l|}{95} \\
\hline 96 & & & & $\begin{array}{l}\text { Központosított, osztály- } \\
\text { tagozódású vállalati } \\
\text { szervezet }\end{array}$ \\
\hline 97 & & Árusító automaták & Vállalati reklámirodák & \\
\hline 98 & $\begin{array}{l}\text { Munkahelyi } \\
\text { idő́tanulmányok }\end{array}$ & $\begin{array}{l}\text { Ingyenes } \\
\text { házhozszállítás vidéken }\end{array}$ & & \\
\hline 99 & & & $\begin{array}{l}\text { Millió dolláros } \\
\text { hirdetési kampány }\end{array}$ & \\
\hline 1900 & & & & $\begin{array}{l}\text { Automatikus } \\
\text { kártyaosztályozó }\end{array}$ \\
\hline 01 & & & $\begin{array}{l}\text { Modern } \\
\text { reklámügynökségek }\end{array}$ & \\
\hline 02 & & Automaták & & $\begin{array}{l}\text { Dugaszolós } \\
\text { kapcsolótábla }\end{array}$ \\
\hline 03 & \begin{tabular}{|l|}
$\begin{array}{l}\text { Automatikusan vezérelt } \\
\text { feldolgozó } \\
\text { üzemegységek }\end{array}$ \\
\end{tabular} & $\begin{array}{l}\text { Kábelösszeköttetés a } \\
\text { Csendes - óceán partjai } \\
\text { között }\end{array}$ & Hirdetési tankönyvek & \\
\hline \multicolumn{5}{|l|}{04} \\
\hline 05 & & Karórák & & \\
\hline 06 & \begin{tabular}{|l|} 
"Line-and-staff” \\
rendszerú üzemirányítás
\end{tabular} & & & Copy-testing \\
\hline 07 & & $\begin{array}{l}\text { Transzatlanti } \\
\text { rádiókapcsolat }\end{array}$ & & \\
\hline \multicolumn{5}{|l|}{08} \\
\hline 09 & $\begin{array}{l}\text { Részlegesen } \\
\text { automatizált vezérlésû́ } \\
\text { szerelőszalag }\end{array}$ & Pörgettyús iránytû́ & & \\
\hline 1910 & & $\begin{array}{l}\text { Kétirányú automatikus } \\
\text { rádiókapcsolat }\end{array}$ & $\begin{array}{l}\text { szabványosított } \\
\text { piackutatás }\end{array}$ & Fénymásolás \\
\hline 11 & $\begin{array}{l}\text { Tudományos } \\
\text { menedzsment }\end{array}$ & & & \\
\hline 12 & & Franchise-rendszer & $\begin{array}{l}\text { Postai csomagküldó } \\
\text { vállalatok hirdetéseinek } \\
\text { ellenőrzése }\end{array}$ & \\
\hline 13 & $\begin{array}{l}\text { Automatikusan vezérelt } \\
\text { szerelőszalag }\end{array}$ & Csomagposta & & \\
\hline 14 & & $\begin{array}{l}\text { Pörgettyús stabilizátor } \\
\text { a repülésben }\end{array}$ & $\begin{array}{l}\text { Sajtótermékek } \\
\text { példányszámának } \\
\text { revíziója }\end{array}$ & \\
\hline
\end{tabular}




\begin{tabular}{|c|c|c|c|c|}
\hline 15 & $\begin{array}{l}\text { Felügyelet nélküli } \\
\text { mellékállomások }\end{array}$ & & & \\
\hline 16 & & Önkiszolgáló üzletek & Háztartási piackutatás & \\
\hline 17 & $\begin{array}{l}\text { River Rouge } \\
\text { feldolgozási rendszer }\end{array}$ & & & \\
\hline 18 & & Légiposta, Fedwire & & \\
\hline 19 & & & Piackutatási tankönyvek & Nyomdai tabulátor \\
\hline 1920 & & $\begin{array}{l}\text { Automatikus } \\
\text { bélyegzôgéppel } \\
\text { bérmentesített } \\
\text { postai küldemények }\end{array}$ & & \\
\hline 21 & & $\begin{array}{l}\text { Autó-behajtós kiszolgáló } \\
\text { intézmények }\end{array}$ & & $\begin{array}{l}\text { Postaköltség- } \\
\text { meghatározó gép }\end{array}$ \\
\hline 22 & $\begin{array}{l}\text { Távirányítás az } \\
\text { elektromos energia } \\
\text { átvitelében }\end{array}$ & Bevásárlóközpontok & $\begin{array}{l}\text { Kereskedelmi } \\
\text { rádióállomások }\end{array}$ & \\
\hline 23 & & Szupermarketek & & $\begin{array}{l}\text { Elektromos } \\
\text { kártyalyukasztók }\end{array}$ \\
\hline 24 & & $\begin{array}{l}\text { Transzkontinentális } \\
\text { légiposta, fakszimile }\end{array}$ & & Országos rádióhálózat \\
\hline 25 & $\begin{array}{l}\text { Keresleti visszajelzésen } \\
\text { alapuló szabályozás }\end{array}$ & & & $\begin{array}{l}\text { Decentralizált vállalati } \\
\text { szervezet }\end{array}$ \\
\hline 26 & & & $\begin{array}{l}\text { Szárazhulladék } \\
\text { felmérések }\end{array}$ & \\
\hline $\begin{array}{l}27 \\
28\end{array}$ & $\begin{array}{l}\text { Pneumatikus } \\
\text { arányszabályozó }\end{array}$ & $\begin{array}{l}\text { Transzatlanti } \\
\text { telefonösszeköttetés }\end{array}$ & Villogó fényreklámok & Többregiszteres \\
\hline 29 & & Repülőgépek & $\begin{array}{l}\text { Rádiós } \\
\text { termékminôsítés, }\end{array}$ & összeadógép \\
\hline 1930 & Minőségellenôrzési & & autórádiók & \\
\hline 31 & tanfolyamok, tankönyvek & & & \\
\hline 32 & & Telex-szolgáltatás & & \\
\hline 33 & $\begin{array}{l}\text { PID-szabályozó } \\
\text { (arányos integráló- }\end{array}$ & & $\begin{array}{l}\text { Kiskereskedelmi } \\
\text { eladási index }\end{array}$ & $\begin{array}{l}\text { Számítások elvégzésére } \\
\text { összekapcsolt gépek }\end{array}$ \\
\hline 34 & differenciáló szabályozás & & & \\
\hline 35 & Pneumatikus jelátvitel & & Országos szintû́ & Elektromos írógép \\
\hline 36 & Laboratóriumi elemzés & Modern koaxiális & $\begin{array}{l}\text { közvéleménykutatás } \\
\text { Audiométeres árszabás }\end{array}$ & \\
\hline 37 & a minőségellenôrzéshez & kábelek & & \\
\hline 38 & & & & \\
\hline 39 & $\begin{array}{l}\text { Emberi kapcsolatok } \\
\text { tankönyve }\end{array}$ & $\begin{array}{l}\text { Radar } \\
\text { Transzatlanti légiposta }\end{array}$ & $\begin{array}{l}\text { Mozgó fényreklám } \\
\text { Kereskedelmi televíziok }\end{array}$ & $\begin{array}{l}\text { Elektronikus } \\
\text { számológép }\end{array}$ \\
\hline
\end{tabular}


Hasonló periodicitás figyelhetô meg az információfeldolgozási, kommunikációs és szabályozási technika fejlődésében is. A gazdaság fố szektorai arra hajlottak, hogy kiaknázzák az információs technológia valamely sajátságos területét: a szállítmányozás a bürokratikus szervezetek fejlesztésére koncentrált; a termelés az anyagfeldolgozás megszervezésére helyezte a hangsúlyt, ideértve az előzetes feldolgozást, a munkamegosztást és a funkciók szerinti specializációt; az elosztás a telekommunikációra épített; a marketing pedig a tömegtájékoztatási eszközöket használta fel. Ezek a kapcsolatok alakították ki - kombinált összefüggésben a fent tárgyalt három gazdasági szektor viszonyaival - a XIX. századi irányítási technológia rendszerét, ahogyan azt a 10.2-es táblázat mutatja.

A legtöbb hivatali szervezeti újítás válaszként jött létre a vasutaknál bekövetkezett irányítási válságra. Az 1860-as évek végére a nagy kereskedőházak már teljesen ki is aknázták az irányításnak ezen új formáit. Az irányítási válság átterjedését az elosztásba a távközlési újítások (a távíró, a postai reformok és a telefon) követték. A szervezési technika és az elôzetes anyagfeldolgozás terén tett újítások ("shop-order" könyvviteli rendszer, szállítmány-irányítási szelvények, árszabási osztályok, költségellenôrzés, egységes számviteli eljárások, üzemi munkafelügyelők és speciális feladatokkal megbízott üzemi tisztviselók alkalmazása) folytatták az 1870-es években az irányítási válság útját a termelési szektorba. A tömegek befolyásolását szolgáló legtöbb újítás (egész oldalas újsághirdetés, védjegytörvény, nyomdai szabadalom, vállalati reklámosztály, millió-dolláros hirdetési kampány, fogyasztóbarát csomagolás) az 1870-es évtized után jelent meg, követve a folyamatos üzemú gyártás beköszöntését és a fogyasztás irányításából adódó válságjelenségeket. Mindezeknek az újításoknak a kíséretében léptek színre gyakorlatilag mindazok az alapvetô tömegkommunikációs technikai eszközök, amelyek még ma is - egy évszázaddal késő́bb - mind használatban vannak: a fotográfia, a rotációs nyomda, a mozi, a drótnélküli távíró, a magnetofon és a rádió.

Az irányítás forradalma - amellett, hogy a tömegtájékoztatási és távközlési eszközök terén ilyen gyors fejlődéshez vezetett - bár növekvő mértékú centralizációval, de lehetővé tette az ipari forradalom során több helyi szinten elveszett gazdasági és politikai irányítás bizonyos mértékủ helyreállítását is. Ezt megelőzôen a kormányok és a piac által gyakorolt ellenőrzés személyes kapcsolatoktól és közvetlen találkozásoktól függött; az 1890-es évekre azonban már megkezdődött az irányítás újjászervezése, elsôsorban bürokratikus szervezeti eszközökkel, továbbá az új távközlési és közlekedési infrastruktúra segítségével és az új tömegtájékoztatási eszközök nyújtotta széles körű kommunikációs lehetôségek révén.

Ha azonban az irányítás forradalma alapvetően válasz volt az ipari forradalomra, miért nem mutatja semmi jelét még ma sem - több, mint egy évszázad után - annak, hogy lendülete alábbhagyna? Úgy tûnik, hogy lankadatlan továbbfejlődését három erố tartja fenn. Először is: az energiafelhasználás, a feldolgozási sebesség és az irányítási technika továbbra is együttesen fejlődik, pozitív visszacsatolású spirálban összefonódva, miközben bármelyik gazdasági szektorban tett előrelépések további fejlődést okoznak - vagy legalábbis lehetôvé teszik azt - a másik kettôben. Másodszor: az újabban elérhetôvé vált technika nemcsak az anyagfeldolgozás és a szállítás sebességét növelte meg, hanem a szállítandó, illetve feldolgozott anyagok mennyiségét és az anyagáramlás elôreláthatóságát is. Ez viszont tovább növelte mind az irányításra, 
mind pedig az információs technológia új alkalmazásainak a hasznosítására támasztott igényeket. A termelés volumenének növekedése például további előnyöket hozott magával a megnövelt fogyasztásban, melynek irányítására a gyártók a piackutatás és a tömeges hirdetési tevékenység eszközeinek felhasználásával törekednek. Hasonlóképpen a termelés és az elosztás nagyobb megbízhatósága növelte az olyan információs tevékenységek gazdasági előnyeit, mint például a tervezés, a pontos időbeosztás és az elốrejelzés. Harmadszor: az információfeldolgozás és az információáramlás maga is irányítást igényel, s ennélfogva az információs technológiákat az irányítás egyre magasabb és magasabb szintjein kell továbbra is folyamatosan alkalmazni, ami kétségkívül ironikus csavart jelent az irányítási forradalom történetében.

\section{Az információ szerepe az irányításban}

Ha azt állítják, hogy az irányítás terén zajló forradalom válaszként kezdődött egy olyan válságra, amit viszont az ipari forradalom váltott ki, fel kell tennünk a kérdést, hogy az információfeldolgozás, előfeldolgozás, programozás és kommunikáció technológiái miért játszottak olyan nagy szerepet az irányítási forradalomban? Röviden: miből fakad az információ új, központi fontossága?

Sem a múszaki újítások tanulmányozása, sem a gazdaságtörténet nem remélheti, hogy egyedül választ tud adni erre a kérdésre, mint ahogyan a szerves élet evolúciójának története sem képes önmagában megmagyarázni az információ jelentôségét minden élő dolog szempontjából. Az okokat, amiért az információ döntô szerepet játszik, egyik esetben sem a történeti részletekben fogjuk megtalálni, hanem inkább minden élő rendszer sajátos természetében - végső soron az információ és az irányítás között fennálló kapcsolatban. Magához az élethez hozzátartozik a célratörő tevékenység és ennélfogva az irányítás is, a nemzetgazdaságok és az egyedi organizmusok esetében is. Az irányítás viszont az információtól és az információt magukban foglaló tevékenységektől - információfeldolgozástól, programozástól, döntésektôl és kommunikációtól - függ.

Az irányítástól elválaszthatatlanok az információfeldolgozás és a kölcsönös kommunikáció iker-tevékenységei. Az információfeldolgozás alapvetôen fontos minden célszerű tevékenységnél. Az irányító és az irányított között kétirányú kölcsönhatás szükséges, hogy az előbbi befolyást gyakorolhasson az utóbbira és ennek eredményei visszafelé is közvetíthetốk legyenek (visszacsatolás).

Minden egyes múszaki újítás gazdagítja azokat a folyamatokat, amelyek fenntartják az ember társadalmi életét, s ezáltal továbbnöveli az irányítás és a hatékonyabb irányítási technológia iránti igényt. Úgy tûnik tehát, hogy a technológia önmagában technológiát szül, vagyis az anyag- és energiafeldolgozás terén létrejövô újítások szükségletet teremtenek további újitásokra az információfeldolgozás és a kommunikáció területén. Mivel a múszaki újítás egyre inkább kollektív erôfeszítést kíván, melynek eredményeit tanítani és terjeszteni kell, növekvő igény keletkezik az információtárolás és visszakeresés technológiájával szemben is.

Az irányítási válság megoldására alkalmazott módszerek között kiemelkedô jelentôségû́ volt - amennyiben a legtöbb más irányítási technológiára is pozitív hatást gyakorolt - a formális hivatali szervezetek gyors növekedése és racionalizálása a XIX. 
század utolsó évtizedeiben. A racionalizáció magában foglalja azt, amit a számítógéptudomány múvelôi ma elôfeldolgosásnak neveznek: kiegészítést ahhoz az irányításhoz, amit a bürokrácia az információfeldolgozáson keresztül végez, növekvő mértékben felhasználva a számítógépeket és mikroprocesszorokat. Minden racionalizációs törekvés közül talán a leginkább átható erejû az az egyre fokozódó tendencia, hogy szabályozzák a személyes kapcsolatokat, mégpedig személytelen, számszerúsíthető és objektív kritériumok formális készletének felállításával, olyan változásokat elóidézendő, amelyek nagymértékben elôsegítik mind a kormányok, mind pedig az üzleti élet által az egyes emberek fölött gyakorolt ellenőrzést. A komplex társadalmi rendszereknek, amelyek a kapitalizmus elterjedésével emelkedtek fel és tökéletesítették a szállítás és a kommunikáció eszköztárát, nem felelt volna meg többé semmiféle olyan az iparosítás elốtti társadalmakra jellemző - információfeldolgozási rendszer, ami esetenkénti alapon vagy partikuláris családi és rokoni kapcsolatok tekintetbevételével múködött volna.

Az információ növekvô jelentőségét a modern gazdasági életben más oldalról világíthatjuk meg, ha az élő szervezetek és rendszerek célratörő természetéből indulunk ki. Végtére is minden gazdasági tevékenység lényegénél fogva céltudatos, és a céljainak elérését szolgáló különféle folyamatok fenntartásához irányításra van szükség. Mivel az irányítás az információtól és az információs tevékenységektôl függ, ezek - egyrészt mint árucikkek, másrészt mint szolgáltatások - belépnek a piacra, méghozzá szoros összefüggésben az adott gazdaság irányításrả való igényével. Ha azonban az irányítás ténylegesen minden élố rendszerben kulcsszerepet játszik, akkor vajon miért növekedett meg oly hirtelen a gazdaság igénye az irányításhoz szükséges információs árukra és szolgáltatásokra, elősegítve az információs társadalom kialakulását? A gazdasági tevékenység valóban függ az irányítástól, az irányítás pedig az információtól, de ezek a kapcsolatok vajon miért tûnnek annyival fontosabbnak ma, mint egy évszázaddal ezelőtt?

\section{Az információs társadalom}

Az információs társadalom kialakulása nem újabban bekövetkezett változások eredménye, inkább az anyagi termelésben és a gazdasági életben több mint száz évvel korábban megindult áramlatok felgyorsulásáé. Hasonlóképpen - a napjainkban divatos felfogással szemben - az elektronikus adatfeldolgozás és a számítástechnika elôtérbe kerülése sem képvisel olyan új erốt, ami csak az utóbbi időben tört volna rá a felkészületlen társadalomra, hanem csupán az irányítási forradalom folyamatos kibontakozásának legújabb szakaszát jelenti. Ez lehet arra a magyarázat, hogy Charles Babbage-hez hasonló látnokok és a Daniel McCallum-féle gyakorlatias újítók miért láthatták előre a modern számítógépes vezérlés és irányítás oly sok alkotóelemét már a tizenkilencedik század első felében.

Az iparosítás tizenkilencedik századi fejlődése és az irányítás ebből következő válsága; továbbá az erre adott múszaki fejlesztési és gazdasági válasz, ami beindította az irányítási forradalmat; valamint az információs társadalom folytatódó kibontakozása - beleértve az információtechnológia most kialakuló telematikus korszakát együttesen döntố szerepet játszik gyakorlatilag az összes, korunk megfigyelői által le- 
írt társadalmi jelenségben. Ide tartozik a felemelkedő új - információs - társadalmi osztály (Djilas, 1957; Gouldner, 1979), az információs dolgozók teljesítményelvú társadalma (Young, 1958), a poszt-kapitalista társadalom (Dahrendorf 1959), az új tömegmédia és a távközlés központi szerepére épülő globális falu (McLuhan, 1964), a nagyvállalatok által egyre növekvố mértékben ellenôrzött és irányított új típusú ipari állam (Galbraith, 1967), a tudományos-technikai forradalom (Richta, 1967; Daglish, 1972; Prágai Akadémia, 1973), a „technotronikus” korszak (Brzezinski, 1970), a poszt-indusztriális társadalom (Touraine, 1971; Bell, 1973), az információs gazdaság (Porat, 1977) és a „mikro-millenium” (Evans, 1979) is.

Ha megvizsgáljuk a különféle átalakulásokat, amelyeket a fent említett megfigyelốk feltártak, azt látjuk, hogy ezek a változások mind az irányítási forradalom jelentôsebb következményei közé sorolhatóak. A fóbb tényezôk közül kiemelkedik az információs technológia fontosságának növekedése, az információs gazdaság és az azt irányító vállalati és állami apparátusok párhuzamos gyarapodása, az irányítás szervezeti bázisának kialakulása és ennek hatása a társadalom szerkezetére (legyen az Young meritokráciája vagy Djilas új társadalmi osztálya), az információfeldolgozás és a kommunikáció központi szerepe McLuhan globális falujában, Bell poszt-indusztriális társadalmának információs megalapozottsága, valamint az információ és a tudás növekvő súlya mindenütt a modern kultúrában. Röviden: ha figyelmünket az információfeldolgozás, a kommunikáció és az irányítás lényeges tényezőire összpontosítjuk, ez a jelenkori társadalom változásaira vonatkozó tudományos ismereteink nagy részét felölelő szintézis megalkotásának lehetôségével kecsegtet.

Korunk társadalmának megértésében kétségkívül fontos szerepet játszanak az irányítási forradalom jelenségei, különösen a számítógépek és a mikroelektronikai eszközök egyre erôsödő hatásai, számunkra azonban a leghasznosabb tanulságot a társadalmi élet általánosabb szintư megértése jelenti. Magának az információs társadalomnak a kialakulása - még inkább, mint akár a formális információelmélet ezzel párhuzamos fejlôdése - ráirányította a figyelmet az információfeldolgozás, a kommunikáció és az irányítás központi jelentőségére, az emberi társadalom és a társadalmi viselkedés szinte valamennyi aspektusát tekintve. Úgy vélem, hogy mi, társadalomtudósok éppen ezeknek az információval kapcsolatos alapvetố fogalmaknak a segítségével remélhetjük tisztázni és egyszerûsíteni a társadalom szerveződésével és a társadalmi folyamatokkal kapcsolatban már gazdagon burjánzó, de még mindig nagyrészt rendszerezetlen ismereteinket.

$$
\text { Rohonyi András fordítása }
$$

James R. Beniger: The Control Revolution címú, az Infonia Alapítvány és az AULA Kiadó gondozásában 2002 végén megjelenő könyvének zárófejezete.

James R. Beniger, (1986): The Control Revolution Harvard University Press, Cambridge, Massachusetts, and London, England 